\title{
Effect of the selected species of ciliates on $\beta$-endoglucanase and xylanase activities and fibre disappearance from the rumen of sheep ${ }^{*}$
}

\author{
T. Michalowski, G. Bełżecki, J. J. Pająk and E. Kwiatkowska
}

\author{
The Kielanowski Institute of Animal Physiology and Nutrition. \\ Polish Academy of Sciences \\ 05-110 Jablonna, Poland
}

\begin{abstract}
Three growing Polish Merino rams were defaunated and then consecutively refaunated with Eudiplodinium maggii, Entodinium caudatum and Dasytricha ruminantium. Establishment of Eudiplodinium maggii in the rumen of defaunated animals resulted in the increase of $\beta$-endoglucanase and xylanase activities by about 42 and $46 \%$, respectively $(P<0.01)$. Enzyme activities did not change following the development of Entodinium caudatum whereas significantly decreased $(\mathrm{P}<0.01)$ when Dasytricha ruminanium was added to Entodinium caudatum and Eudiplodinium maggii.

Rumen digesta weight tended to increase following the consecutive refaunations. ADF and NDF in rumen digesta varied in the range of $4.1-5.6$ and $6.5-7.9 \%$, respectively, and increased significantly after establishment of Entodinium caudatum and Dasytrich a ruminantium. Disappearance rate of ADF and NDF was affected by the microfauna composition and varied from 0.21 to 0.30 and from 0.36 to $0.50 \mathrm{~kg} / 12 \mathrm{~h}$, respectively. Establishment of Entodinium caudatum and Dasytricha ruminantium in the rumen was accompanied by decrease in disappearance rate of ADF and NDF $(\mathrm{P}<0.01)$. The negative correlation was found between both the ADF and NDF contents in rumen digesta and their disappearance rate from the rumen.
\end{abstract}

KEY WORDS: ciliates, sheep, $\beta$-endoglucanase, xylanase activities, fibre disappearance

\section{INTRODUCTION}

Ruminants depend on fibrolytic microorganisms in utilization of energy from the structural carbohydrates in forages. Of protozoa inhabiting in the rumen some

\footnotetext{
* Supported by the State Committee for Scientific Research, Grant No. 5 PO6E03615
} 
species of the genus Diplodinium seem to participate in digestion of the fibrous feed (Dehority, 1993) whereas Entodinia affect this process influencing positively the population of fibrolytic bacteria (Ushida et al., 1991). Role of ruminal holotrichs is not clear but decreasing effect can not be precluded presumably due to lactic acid production (Van Hoven and Prins, 1977). The data cited here suggest that cellulose and hemicellulose degradation in the rumen can be influenced by the microfauna composition.

The aim of this study was to estimate $\beta$-endoglucanase (CMC-ase) and xylanase activities in the rumen digesta as well as ADF and NDF disappearance from the rumen of defaunated sheep and following their refaunation with fibrolytic ciliate alone or accompanied by either starch or starch and soluble carbohydrates preferring species of protozoa.

\section{MATERIAL AND METHODS}

Three growing Polish Merino rams weighing about $40 \mathrm{~kg}$ at the beginning of the study and fitted with large rumen cannulas were used. The animals were kept in separate pens with the solid walls and fed $750 \mathrm{~g}$ hay and $130 \mathrm{~g}$ ground barley every $12 \mathrm{~h}$ while access to the water was free.

The study composed of four experimental periods during which the sheep were either ciliate free (Period 1) or refaunated only with fibrolytic Eudiplodinium maggii (Period 2); with Eudiplodinium maggii and strach preferring Entodinium caudatum (Period 3) or with the both mentioned species of ciliates plus Dasytricha ruminantium preferentially utilized soluble carbohydrates (Period 4). Eudiplodinium maggii and Entodinium caudatum used in refaunation procedure originated from in vitro cultures. Dasytricha ruminantium ciliates were picked from the diluted rumen fluid of cow and introduced immediately to the rumen of sheep.

Digesta samples for determination of the enzyme activities $(2 \times 40-50 \mathrm{~g})$ and ciliate number $(2 \times 5.0 \mathrm{~g})$ were taken just before morning feeding and $4 \mathrm{~h}$ thereafter. The digesta volume as well as ADF and NDF were determined just before both the morning and evening feeding. For this purpose the digesta was withdrawn from the rumen. It was weighing and sampled $(2 \times 60-70 \mathrm{~g})$ for the fibre fraction estimation and returned back. The sampling was starting not earlier than 3 weeks following defaunation (Period 1 ) or establishment of the protozoa population (Periods 2, 3 and 4). Each sampling was repeated three times on different days of each period. The samples for enzyme activities and ADF and NDF determination were stored at $-20^{\circ} \mathrm{C}$. The samples for protozoa counting were fixed with $4 \%$ aqueous formaldehyde solution.

Enzyme were extracted in the presence of lysozyme using carbon tetrachloride (Huhtanen and Khalili, 1992). The activities of $\beta$-endoglucanase and xyla- 
nase were determined by measurement of reducing sugars released from carboxymethylcellulose (CMC) and xylan during incubation with enzyme solution for $1 \mathrm{~h}$ at $40^{\circ} \mathrm{C}$ (Groleau and Forsberg, 1981; Huthanen and Khallili, 1992). Glucose and xylose were used as standards, respectively. The activity of each enzyme was expressed as $\mu \mathrm{M}$ sugars released from substrate/g DM of rumen digesta $/ \mathrm{min}$. The samples of rumen digesta were dried at $105^{\circ} \mathrm{C}$ to determine DM while ADF and NDF were estimated according to AOAC (1990). Ciliate protozoa were counted using light microscope.

Mean values were calculated from the obtained data while significance of differences was calculated using Students $t$ test.

\section{RESULTS AND DISCUSSION}

No ciliates were present in the rumen of all three sheep during the first experimental period which shows that defaunation method (Michałowski et al., 1999) was successful. Eudiplodinium maggii was present in the rumen for the next 3 periods; Entodinium caudatum - for the periods 3 and 4 while Dasytricha ruminantium - for the last period only (Table 1). Inoculation of Entodinium caudatum into the rumen resulted in the decrease in the number of Eudiplodinium maggii by about $50 \%(\mathrm{P}<0.01)$. This reaction could be explained as a result of competition between the ciliate species to starch. Establishment of Dasytricha ruminantium had no effect on population density of ciliates already present in the rumen.

Development of Eudiplodinium maggii in the rumen of the ciliate-free sheep led to the increase in both the $\beta$-endoglucanase and xylanase activity (Table 1). An explanation for these findings can be high activity of enzymes produced by mentioned protozoa (Michałowski and Harmeyer, 1998). Establishment of Entodinium caudatum in the rumen of sheep did not affect the enzyme activities in spite of significant decrease in the number of fibrolytic Eudiplodinium maggii (Dehority, 1993). This could be the result of stimulating effect of Entodinium caudatum on development of the fibrolytic bacteria (Ushida et al., 1991). Increase in the number of fibrolytic bacteria could compensate the changes in enzyme activities resulting from diminishing in concentration of Eudiplodinium maggii. Establishment the population of Dasytricha ruminantium resulted in the decrease in both the $\beta$-endoglucanase and xylanase activities $(\mathrm{P}<0.01)$. This suggest a negative effect of small holotrichs on fibrolytic bacteria as the number of ciliates was not influenced.

$\mathrm{ADF}$ and NDF disappearance rate from the rumen of defaunated sheep was 0.27 and $0.50 \mathrm{~kg} / 12 \mathrm{~h}$ and did not change significantly following establishment of Eudiplodinium maggii (Table 1). Appearance of Entodinium caudatum in the rumen led to decrease in disappearance rate of ADF and NDF $(\mathrm{P}<0.05)$ in spite 
TABLE 1

Ciliate numbers and fibrolytic enzyme activities with relation to digesta weight and ADF and NDF contents as well as ADF and NDF disapperance from the rumen of defaunated and differently refaunated sheep

\begin{tabular}{lcccc}
\hline & \multicolumn{4}{c}{ Experimental periods } \\
\cline { 2 - 5 } Item & 1 & 2 & 3 & 4 \\
\hline Eudiplodinium magi $\left(\times 10^{3} / \mathrm{g}\right)$ & 0.0 & $22.8^{\mathrm{a}}$ & $11.8^{\mathrm{b}}$ & $10.8^{\mathrm{b}}$ \\
Entodinium caudatum $\left(\mathrm{x} 10^{\mathrm{3}} / \mathrm{g}\right)$ & 0.0 & 0.0 & 268.7 & 285.0 \\
Dasytricha ruminantium $\left(\times 10^{3} / \mathrm{g}\right)$ & 0.0 & 0.0 & 0.0 & 53.4 \\
Other ciliates & not present & not present & not present & not present \\
& & & & \\
$\beta$-endoglucanase in rumen digesta, & & & & \\
$\mu$ M glucose/g DM/min & $4.0^{\mathrm{a}}$ & $5.7^{\mathrm{bc}}$ & & \\
$\beta$-xylanase in rumen digesta, & & & & $5.3^{\mathrm{c}}$ \\
$\mu \mathrm{M}$ xylose/g DM/min & $38.9^{\mathrm{a}}$ & $55.1^{\mathrm{b}}$ & $52.4^{\mathrm{b}}$ & $46.4^{\mathrm{c}}$ \\
& & & & \\
Rumen digesta weight, $\mathrm{kg}$ & $8.9^{\mathrm{a}}$ & $9.1^{\mathrm{a}}$ & $9.6^{\mathrm{a}}$ & $10.1^{\mathrm{a}}$ \\
ADF in rumen digesta, $\%$ & $4.4^{\mathrm{a}}$ & $4.1^{\mathrm{a}}$ & $5.0^{\mathrm{b}}$ & $4.8^{\mathrm{b}}$ \\
NDF in rumen digesta, $\%$ & $6.7^{\mathrm{a}}$ & $6.5^{\mathrm{a}}$ & $7.5^{\mathrm{b}}$ & $7.9^{\mathrm{c}}$ \\
ADF disapperance rate, $\mathrm{kg} / 12 \mathrm{~h}$ & $0.27^{\mathrm{ab}}$ & $0.30^{\mathrm{a}}$ & $0.26^{\mathrm{b}}$ & $0.21^{\mathrm{c}}$ \\
NDF disapperance rate, $\mathrm{kg} / 12 \mathrm{~h}$ & $0.50^{\mathrm{a}}$ & $0.50^{\mathrm{a}}$ & $0.42^{\mathrm{b}}$ & $0.36^{\mathrm{c}}$ \\
\hline
\end{tabular}

$\mathrm{ADF}$ and NDF disapperance was calculated from their content in the ration and in the rumen digesta before the morning and evening feeding.

values marked with different letters differ significantly $(\mathrm{P}<0.05)$

of high activity of the enzyme tested. This suggests that no correlation can exist between both the $\beta$-endoglucanase and xylanase activities in the rumen digesta and ADF and NDF disappearance from the rumen. Development of Dasytricha ruminanium caused the significant decrease in disappearance rate of ADF and NDF from the rumen $(\mathrm{P}<0.01)$. This last finding is in good accordance with earlier observation (Ushida et al., 1991; Ivan at al., 2000) as well as with changes in fibrolytic enzyme activities presented in this paper (Table 1). It is possible that Dasytricha ruminantium influenced negatively the development of fibrolytic bacteria. Reduction in bacteria number was not compensated by the increase in the number of the fibrolytic Eudiplodinium maggii and due to this a decrease in both the fibrolytic enzyme activities and ADF and NDF disappearance from the rumen were observed.

The obtained results showed relationship between microfauna composition and ADF and NDF digestion and/or outflow from the rumen. Decrease in disappearance of the both fibre fractions resulted in increase their contents in rumen digesta (Figure 1) and increment in digesta volume. 


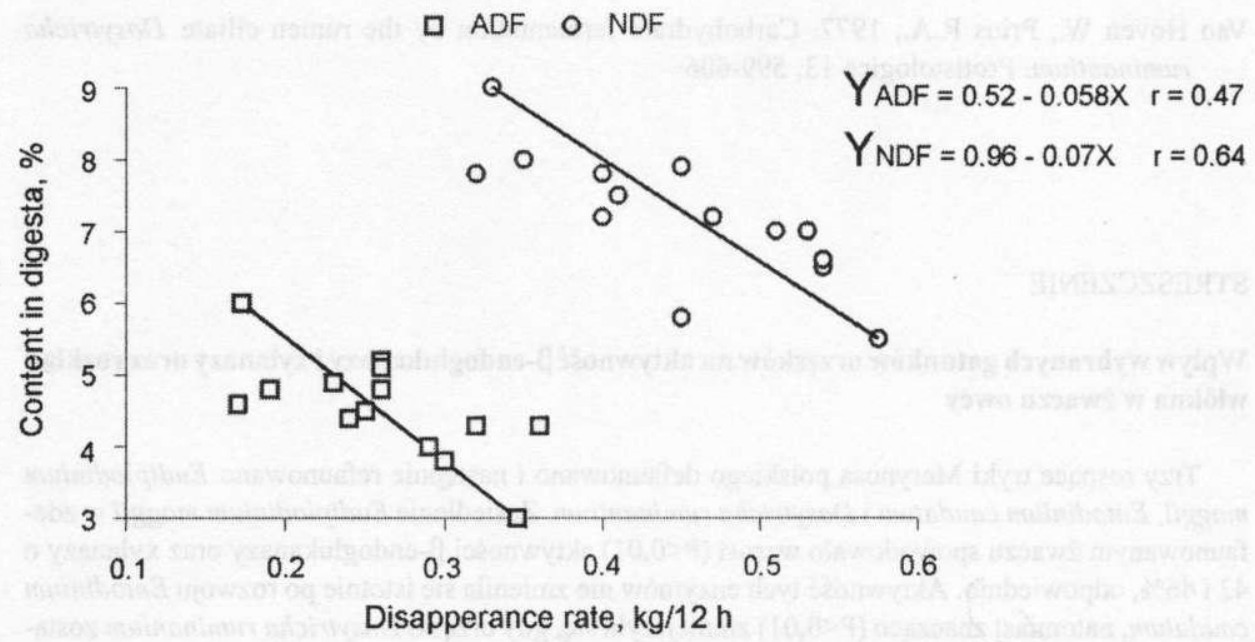

Figure 1. Relationships between both the ADF and NDF disappearance rate from the rumen and their contents in the rumen digesta

\section{REFERENCES}

AOAC, 1990. Association of Official Analytical Chemists. Official Methods of Analysis. $15^{\text {th }}$ Edition. Arlington, VA

Dehority B.A., 1993. Microbial ecology of cell wall fermentation. In: H.G. Jung, D.R. Buxton, R.D. Hatfield, J. Ralf (Editors). Forage Cell Wall Structure and Digestibility. ASA, Inc. CSSA, Inc. SSSA, Inc. Madison, Wisconsin (USA), pp. 425-453

Groleau D., Forsberg C.W., 1981. Cellulolytic activity of the rumen bacterium Bacteroides succinogenes. Can. J. Microbiol. 27, 517-530

Huhtanen P.P., Khalili H., 1992. The effect of sucrose supplements on the particle associated carboxymethylcellulase (EC 3.2.1.4) and xylanase (EC 3.2.1.8) activities in cattle given grasssilage-based diet. Brit. J. Nutr. 67, 245-255

Ivan M., Neill L., Forster R., Alimon R., Rode L.M., Entz T., 2000. Effect of Isotricha, Dasytricha, Entodinium and total fauna on ruminal fermentation and duodenal flow in wethers fed different diets. J. Dairy Sci. 83, $776-787$

Michałowski T., Harmeyer J., 1998. The effect of rumen ciliates Eudiplodinium maggii on the xylanase and CMC-ase activity in sheep. In: J.A.M. van Arendonk (Editor). Book of Abstracts of the 49th Annual Meeting of the European Association for Animal Production. Wageningen Pers, Wageningen, p. 86

Michałowski T., Harmeyer J., Bełżecki G., 1999. The importance of washing the omasum for successful defaunation of sheep. J. Anim. Feed Sci. 8, 611-619

Ushida K., Jouany J.-P., Demeyer D., 1991. Effects of presence or absence of rumen protozoa on the efficiency of utilization of concentrate and fibrous feeds. In: T. Tsuda, Y. Sasaki, R. Kawashima (Editors). Physiological Aspects of Digestion and Metabolism in Ruminants. Academic Press, Inc. San Diego, pp. 625-654 
Van Hoven W., Prins R.A., 1977. Carbohydrate fermentation by the rumen ciliate Dasytricha ruminantium. Protistologica 13, 599-606

\section{STRESZCZENIE}

Wpływ wybranych gatunków orzęsków na aktywność $\beta$-endoglukanazy i xylanazy oraz rozklad wlókna w żwaczu owcy

Trzy rosnące tryki Merynosa polskiego defaunowano i następnic rcfaunowano Eudiplodinium maggii, Entodinium caudatum i Dasytricha ruminantium. Zasiedlenic Eudiplodinium maggii w zdefaunowanym żwaczu spowodowało wzrost $(\mathrm{P}<0,01)$ aktywności $\beta$-endoglukanazy oraz xylanazy o 42 i 46\%, odpowiednio. Aktywność tych enzymów nie zmieniła się istotnie po rozwoju Entodinium caudatum, natomiast znacząco $(\mathrm{P}<0,01)$ zmnicjszyła sic̨, gdy orzęski Dasytricha ruminanium zostaty dodawane do Entodinium caudatum i Eudiplodinium maggii.

Stwierdzono tendencję wzrostu masy treści żwacza w następstwie refaunacji. ADF i NDF w treści żwacza stanowiły 4,1-5,6 oraz 6,5-7,9\%, odpowicdnio, i zwiçkszały sic̨ znacząco po rozwinięciu się populacji Entodinium caudatum i Dasytricha ruminantium. Tempo ubytku ADF i NDF ze żwacza zależalo od skladu mikrofauny i wynosiło od 0,21 do 0,30 oraz od 0,36 do $0,50 \mathrm{~kg} / 12$ godz., odpowiednio. Zasiedleniu żwacza przez Dasytricha ruminantium towarzyszyło zmniejszenie $(\mathrm{P}<0,01)$ tempa ubytku ADF i NDF w żwaczu.

Stwicrdzono ujemną korelację między tempem ubytku ADF i NDF a ich zawartością w treści żwacza. 